\title{
STRATEGI STORE ENVIRONMENT DAN TIME PRESSURE PADA PEMBELIAN IMPULSIF MELALUI EMOTIONAL STATE
}

\section{Enrique Made Reidia Gana Purwa, Ni Nyoman Kerti Yasa ${ }^{\bowtie}$}

Fakultas Ekonomi dan Bisnis, Universitas Udayana, Bali, Indonesia

\begin{tabular}{l} 
Info Artikel \\
\hline Sejarah Artikel: \\
Diterima Juni 2014 \\
Disetujui Juli 2014 \\
Dipublikasikan September 2014 \\
\hline Keywords: \\
Store Environment; \\
Time Pressure; \\
Emotional State; \\
Impulsive Purchases \\
\hline
\end{tabular}

\begin{abstract}
Tujuan dari penelitian ini adalah menganalisis dan menjelaskan pengaruh dari store environment dan time pressure terhadap pembelian impulsif yang dimediasi emotional state. Populasi dalam penelitian ini adalah pengunjung Tiara Dewata Super Market. Metode penentuan sampel yang digunakan adalah purposive sampling, sebanyak 130 responden. Teknik analisa yang digunakan adalah Structural Equation Model (SEM) dan uji sobel. Hasil penelitian menunjukkan bahwa store environment dan time pressure berpengaruh positif dan signifikan terhadap emotional state dan pembelian impulsif; emotional state berpengaruh positif dan signifikan terhadap pembelian impulsif; dan emotional state signifikan dalam memediasi pengaruh store environment dan time pressure terhadap pembelian impulsif. Dengan penelitian ini, diharapkan berguna bagi pihak manajemen Tiara Dewata Super Market untuk membantu dalam meningkatkan jumlah kunjungan dan peningkatan pembelian dengan pengoptimalan dari lingkungan toko.
\end{abstract}

\section{THE STRATEGY OF STORE ENVIRONMENT AND TIME PRESSUSRE ON IMPULSIVE PURCHASES TROUGH EMOTIONAL STATE}

\begin{abstract}
Abstrak
The objective of the study was to analyze and explain the influence of store environment and time pressure toward impulsive purchases mediated by emotional state. The population of this study was the visitors Tiara Dewata Super Market. The sampling method used was purposive sampling, with 130 respondents. The data were analyzed by Structural Equation Model (SEM) and the Sobel test. The results of the study showed that the store environment and time pressure gave significant positive influence toward emotional state and impulsive purchases; emotional state was positive had significant influence on impulsive purchases; emotional state was significant to mediate the influence of store environment and time pressure toward impulse purchases. Thus with this study, it is expected for the management of Tiara Dewata Super Market to increase the visits and purchases by optimalizing the store environment..
\end{abstract}

JEL Classification: M3, M31

\footnotetext{
Alamat korespondensi : 


\section{PENDAHULUAN}

Banyak bisnis perdagangan di Denpasar yang sudah didirikan, salah satunya yang berkembang hingga saat ini adalah bisnis ritel. Ritel merupakan suatu upaya yang dilakukan perusahaan manufaktur dalam mendistribusikan barang-barangnya dalam jumlah yang besar untuk dikonsumsi oleh konsumen dalam memenuhi kebutuhannya (Utami, 2010). Carrefour, Robinson, Matahari, Ramayana, Tiara, Hardys beberapa bisnis ritel di Kota Denpasar. Salah satu ritel lokal yang mampu mempertahankan eksistensinya dalam persaingan bisnis ritel di Kota Denpasar adalah Tiara Dewata Super Market.

Perusahaan ritel tersebut berlombalomba menarik perhatian konsumen dengan mengadakan poin belanja, potongan harga, pemberian hadiah, undian berhadiah dan lain sebagainya. Akan tetapi, para manajer ritel telah sadar bahwa melakukan promosi saja tidaklah cukup, mempelajari perilaku konsumen juga merupakan hal yang penting (Suprapti, 2010). Pembelian impulsif merupakan salah satu perilaku konsumen yang perlu diketahui oleh seorang manajer.

Pembelian impulsif terjadi ketika konsumen mengalami dorongan tiba-tiba, keinginan yang kuat untuk membeli sesuatu dengan segera (Rohman, 2009). Tipe pembelian impulsif kebanyakan muncul ketika seorang konsumen terpengaruh oleh situasi di dalam toko (Solomon, 2009). Keinginan membeli suatu produk dapat datang secara tiba-tiba karena berbagai alasan situasional (Sutisna, 2001). Pemasar dapat menciptakan situasi untuk merangsang pembelian impulsif, khususnya di dalam toko dengan memberikan kenyamanan berbelanja bagi konsumen.

Faktor situasional merupakan lingkungan sementara yang membentuk konteks dalam suatu kegiatan konsumen, yang terjadi pada tempat dan waktu tertentu (Belk, 1975).
Beberapa studi yang telah dilakukan mengenai faktor situasional dalam mempengaruhi keputusan pembelian konsumen masih menunjukkan adanya perbedaan (Lee \& Yi, 2008; Lee \& Kacen, 2008; Mihic \& Kursan, 2010). Sehubungan terjadinya perbedaan penelitian terdahulu mengenai faktor situasional terhadap keputusan pembelian, maka sebelum melakukan penelitian ini akan dilakukan survei pendahuluan.

Menurut survei pendahuluan, 15 orang yang pernah melakukan aktivitas perbelanjaan di Tiara Dewata Super Market, 8 orang diantaranya menyatakan bahwa faktor-faktor yang mempengaruhi mereka dalam melakukan pembelian impulsif adalah lingkungan toko (suasana toko, desain toko, dsb) dan durasi waktu mereka berbelanja. Maka dari itu, variabel yang digunakan dalam faktor situasional yaitu dengan mengambil faktor store environment (lingkungan toko) dan time pressure (tekanan waktu), juga menjadikan emotional state (suasana hati) sebagai faktor mediasinya terhadap keputusan pembelian impulsif.

Dalam beberapa teori, lingkungan fisik sebuah toko mempengaruhi persepsi konsumen melalui mekanisme sensor penglihatan, pendengaran, penciuman dan bahkan sentuhan (Mowen \& Minor, 2002). Store environment utamanya memiliki peran yang penting dalam menciptakan perasaan atau dorongan untuk berbelanja di sebuah toko. Store environment terdiri dari beberapa elemen yaitu: tata ruang toko, ruang lorong, penempatan dan bentuk peraga, warna, pencahayaan, musik, aroma dan temperatur (Engel et al., 2008).

Waktu erat hubungannya dengan faktor situasi pada sebuah toko, yang menunjukkan seseorang konsumen menghabiskan waktu berada di dalam toko. Seorang konsumen yang memiliki waktu yang cukup senggang berbeda dengan konsumen yang hanya memiliki waktu yang relatif sedikit dalam berperilaku. Berdasarkan hal tersebut, maka disimpulkan 
bahwa kecenderungan konsumen melakukan pembelian impulsif didasarkan oleh adanya tekanan waktu atau time pressure (Wu \& Huan, 2010)

Dalam beberapa teori, emotional state sering dikaitkan dengan antecendent state. Memang dari kedua kondisi di atas samasama menunjukkan kondisi saat konsumen berbelanja, akan tetapi terdapat perbedaan pada sedikit definisinya. Menurut Belk (1975), antecendent states merupakan pengaruh situasi yang muncul dari seorang individu tersebut. Sedangkan menurut Octaprinanta et al. (2013), emotional state merupakan suasana hati yang diakibatkan beberapa faktor lingkungan sehingga mendorong konsumen melakukan pembelian impulsif. Berdasarkan latar masalah yang ada, maka yang menjadi tujuan penelitian ini adalah untuk mengetahui pengaruh store environment dan time pressure terhadap pembelian impulsif yang dimediasi emotional state di Tiara Dewata Super Market.

Menurut Nistorescu dan Barbu (2008), desain dan lingkungan dari toko ritel merupakan agregat elemen yang menentukan gaya kerangka materi dari lokasi dan menciptakan suasana khusus untuk konsumen. Store environment terdiri dari beberapa elemen yaitu: tata ruang toko, ruang lorong, penempatan dan bentuk peraga, warna, pencahayaan, musik, aroma dan temperatur (Engel et al., 2008). Berkaitan dengan lingkungan fisik toko, Mowen dan Minor (2002) mengemukakan bahwa terdapat beberapa elemen yang cukup mempengaruhi konsumen, antara lain: musik, kondisi berdesakan, lokasi toko, tata ruang toko dan suasana toko.

Penelitian

Kumar

mengklasifikasikan komponen lingkungan dari toko menjadi ambient, desain, dan sosial. Komponen sosial adalah rangsangan yang mencakup kehadiran karyawan dan pelanggan di toko. Komponen desain adalah rangsangan yang mewakili unsur-unsur visual dari ruang (misalnya, tata letak, warna serta elemen arsitektur) yang ada di garis depan kesadaran seorang konsumen. Komponen ambient adalah stimulus yang mengacu pada unsurunsur nonvisual (misalnya, suhu, musik, dan pencahayaan) dampak yang menyatakan bawah sadar konsumen.

Menurut Graa dan Dani-elKebir (2012), waktu erat berhubungan dengan faktor situasi pada sebuah toko, yang menunjukkan seseorang konsumen menghabiskan waktunya saat berada di sebuah toko. Seorang konsumen yang memiliki waktu yang cukup senggang berbeda dengan konsumen yang hanya memiliki waktu yang relatif sedikit dalam berperilaku.

Penelitian Graa dan Dani-elKebir (2012) mendefinisikan time pressure merupakan ketersediaan waktu untuk pembelanja untuk melakukan tindakan membeli. Tekanan waktu akan membatasi perhatian yang diberikan kepada unsur-unsur lingkungan. Lebih banyak waktu yang konsumen habiskan di toko, semakin berkurang tingkah laku pembelian impulsif. Sedikitnya waktu yang dimiliki seorang konsumen menimbulkan sebuah tekanan waktu yang menjadibatasankeleluasaan untukmemilih dan berpikir lebih lanjut. Hal tersebut memicu munculnya kecenderungan konsumen dengan tekanan waktu tersebut yaitu lebih memilih berkunjung ke tempat perbelanjaan yang relatif lengkap karena tidak perlu membuang waktu berpindah ke toko lainnya, lebih sedikit pertimbangan merek-merek untuk produk yang dibutuhkan, segera meninggalkan toko dan lebih mengabaikan stimulus berbelanja lainnya yang ada pada sebuah toko (Octaprinanta et al., 2013).

Emosi adalah konsep yang tidak stabil yang sulit didefinisikan dan diukur. Apalagi respon emosional yang tidak mudah diingat kembali, dan mereka tidak mudah untuk mendokumentasikan atau verbalisasi (Lee \& Yi, 2008). Menurut Octaprinanta et al. (2013), suasana hati atau emosi seseorang dapat dipengaruhi oleh desain toko, cuaca, atau faktor yang dirasa peka bagi konsumen. Jadi, emosi merupakan salah satu aspek penting yang perlu dipertimbangkan dalam mempengaruhi 
konsumen maupun calon konsumen karena dapat mendorong konsumen melakukan pembelian tanpa bisa ditahan.

Secara khusus, emosi atau suasana hati konsumen dianggap sebagai variabel situasional yang mempengaruhi perilaku pembelian seseorang. Berbagai emosi relevan dengan konsumsi termasuk perasaan cinta, benci, takut, sukacita ,kebosanan, kecemasan, kebanggaan, marah, sedih, keserakahan, rasa bersalah, dan malu (Graa \& Dani-elKebir, 2012). Hubungan antara emosi yang positif sangat berpengaruh dalam perilaku pembelian impulsif (Jondry, 2012). Model Mehrabia dan Russell (1974), tiga tanggapan emosional, yaitu pleasure (kesenangan), arousal (gairah), dan dominance (penguasaan). Penelitian Foroughi et al. (2013), menemukan bahwa untuk mengukur suasana hati yaitu menggunakan happy, satisfied, dan pleased.

Pembelian impulsif atau impulse buying adalah keputusan yang tidak direncanakan untuk membeli produk atau jasa, yang dibuat sebelum pembelian. Dan Muruganantham dan Bhakat (2013), menyimpulkan Impulse buying telah menjadi tantangan bagi para peneliti pasar karena sifatnya yang kompleks. Berdasarkan Octaprinanta et al. (2013), pembelian yang tidak terencana (impulsebuying) dapat dikatakan sebagai perilaku pembelian yang unik. Perilaku impulse buying memiliki empat tipe, yaitu pembelian impulse yang murni (Pure Impulse), pembelian impulse yang dampak tersugesti (Suggestion Impulse), pembelian impulse yang telah direncanakan tetapi tidak secara mendetail produknya (PlannedImpulse) dan pembelian impulse yang berdasarkan ingatan akan persediaan yang dimiliki (Reminder Impulse).

Menurut Chang et al. (2009), store environment mampu memberikan kesenangan dan merangsang pengunjung toko. Suasana hati atau emosi seseorang dapat dipengaruhi oleh desain toko, cuaca, atau faktor yang dirasa peka terhadap konsumen (Octaprinanta et al., 2013).
H1: Store Environment (XI) berpengaruh positif dan signifikan terhadap Emotional State (Y1)

Dalam Myriam dan Oesman (2013), menunjukkan bahwa pembelian impulsif dapat dilakukan oleh eksposisi konsumen di waktu pengalaman belanja ke stimulus lingkungan. Dalam hal yang sama, Chen dan Hsieh (2011) menunjukkan bahwa variabel suasana penjualan (suara, tampilan dan bau) adalah stimulan penting yang dapat menghasilkan keinginan untuk membeli impulsif. Tendai dan Crispen (2009), menunjukkan bahwa pembelian impulsif tampaknya dimotivasi oleh visual konfrontasi dengan produk atau rangsangan lingkungan toko.

$\mathrm{H} 2$ : Store Environment (XI) berpengaruh positif dan signifikan terhadap Pembelian Impulsif (Y2)

Foroughi et al. (2013) menjelaskan bahwa untuk mengukur emosi yang positif (positive emotion), maka happy, satisfied, dan pleased yang digunakan. Sementara, tekanan waktu terhadap positive emotion berdampak negatif, karena tekanan waktu yang sedikit akan membuat konsumen merasakan kesenangan dan kepuasan yang kurang (Graa \& DanielKebir, 2012).

H3: Time pressure (X2) berpengaruh negatif dan signifikan terhadap Emotional State (Yl)

DalamHudan Qin(2014),menyimpulkan dalam proses pembelian impulsif, salah satu faktornya adalah keputusan pembelian yang diambil dalam waktu yang terbatas. Dengan adanya peningkatan tekanan waktu, maka dapat merubah tingkah laku konsumen dalam melakukan pembelian.

Wu dan Huan (2010), menunjukkan bahwa pengaruh tekanan waktu terhadap pembelian impulsif signifikan. Hal ini mungkin 
Enrique Made Reidia Gana Purwa \& Ni Nyoman Kerti Yasa / Strategi Store Environment dan Time Pressure ...

disebabkan oleh fakta bahwa tidak ada waktu yang cukup bagi konsumen untuk mengambil banyak hal yang menjadi pertimbangan. Semakin banyak tekanan waktu konsumen, semakin impulsif perilaku pembelian mereka.

H4: Time pressure (X2) berpengaruh positif dan signifikan terhadap Pembelian Impulsif (Y2)

Pembelian impulsif didasarkan dan didukung secara teoritis dalam keadaan emosional untuk pengambilan keputusan konsumen (Tendai \& Crispen, 2009). Pandangan ini menerangkan bahwa, konsumen cenderung mengasosiasikan beberapa perasaan yang sangat melibatkan emosi atau seperti suka cita, cinta, rasa takut, dan harapan, dengan kegiatan pembelian. Daripada hati-hati mencari, berunding dan mengevaluasi sebelum membeli, sebagian konsumen melakukan pembelian berdasarkan dorongan, keisengan, karena mereka didorong secara emosional. Semua ini menunjukkan bahwa pembelian impulsif, mungkin sebagian besar menjadi perilaku pembelian sadar yang didorong oleh kekuatan afektif di luar kendali individu seperti emosi (Lee \& Yi, 2008).

H5: Emotional State (Yl) berpengaruh positif dan signifikan terhadap Pembelian Impulsif (Y2)

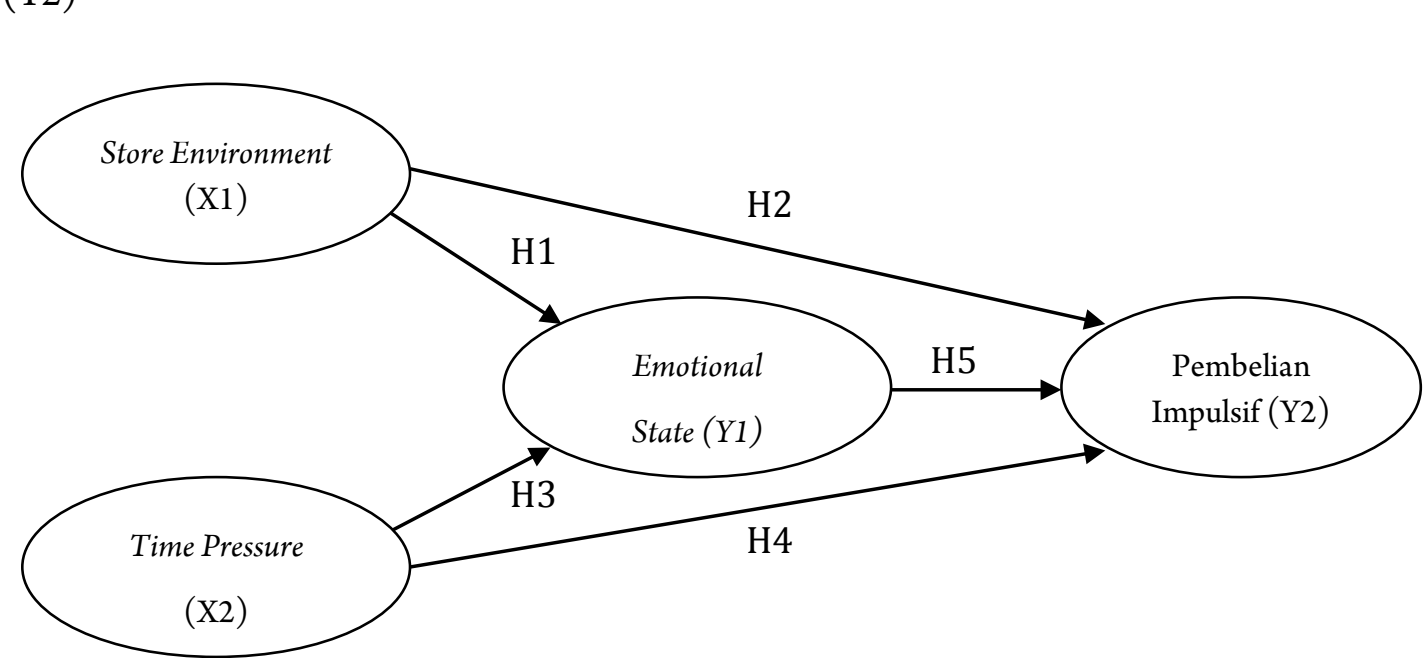

Gambar 1. Model Penelitian
Peningkatan stimulus lingkungan toko yang teraktualisasi dalam hal penataan lingkungan toko dan stimulus yang diberikan berupa musik, aroma, warna, dan ketersediaan produk dapat merangsang emosi positif konsumen sehingga dapat memicu terjadinya pembelian impulsif (Jondry, 2012). Penelitian Sinaga et al. (2012), menyimpulkan hal yang serupa bahwa kondisi emosional konsumen yang disebabkan oleh store environment tampaknya menjadi alasan kuat mengapa konsumen menghabiskan waktu ekstra di tokotoko tertentu, dan menghabiskan uang lebih dari awalnya dimaksudkan.

H6: Emotional State (Y1) memiliki pengaruh positif dan signifikan dalam memediasi Store Environment (X1) terhadap Pembelian Impulsif (Y2)

Menurut model Mehrabian dan Rusell (1974) serta Graa dan Dani-elKebir (2012), menjelaskan peran emotional state dalam memediasi time pressure dan impulse buying. Time Pressure yang dirasakan seorang konsumen memainkan peran sebagai pengaruh emosi dalam melakukan aktivitas pembelian. Emosi yang dirasakan akibat dari tekanan waktu akan berpengaruh terhadap pembelian impulsif. Maka dari itu, dimensi emosi dikatakan sebagai 
mediator yang layak antara tekanan waktu dan pembelian impulsif.

H7: Emotional State (Y1) memiliki pengaruh positif dan signifikan dalam memediasi Time Pressure (X2) terhadap Pembelian Impulsif (Y2)

Berdasarkan rumusan hipotesis penelitian tersebut, diperoleh model penelitian seperti yang disajikan pada Gambar 1.

\section{METODE}

Penelitian ini menggunakan metode asosiatif. Maka hubungan yang diteliti adalah pengaruh variabel Store Environment dan Time Pressure terhadap Pembelian Impulsif yang dimediasi Emotional State pada Tiara Dewata Super Market Denpasar. Lokasi penelitian ini dilakukan di Tiara Dewata Super Market Denpasar. Objek yang akan diteliti dalam penelitian ini adalah pengaruh store environment terhadap pembelian impulsif, pengaruh time pressure terhadap pembelian impulsif, pengaruh store environment terhadap emotional state, pengaruh time pressure terhadap emotional state, pengaruh emotional state terhadap pembelian impulsif dan peran emotional state sebagai mediasi. Pada penelitian ini, klasifikasi variabel dan indikator variabel dapat dilihat dalam Tabel 1.

Dalam penelitian ini, yang menjadi populasi adalah seluruh konsumen yang telah melakukan pembelanjaan di Tiara Dewata Super Market Denpasar. Pengambilan sampel akan dilakukan dengan teknik purposive sampling. Data dalam penelitian ini dikumpulkan dari jawaban atas kuesioner yang dibagikan kepada responden dengan kriterianya telah ditetapkan sebelumnya. Menurut Ferdinand (2002) adalah ukuran sampelyangrepresentatifantara 100-200 sampel atau tergantung pada jumlah parameter yang digunakan dalam seluruh variabel laten, yaitu jumlah parameter dikalikan 5 sampai 10 . Dalam penelitian ini jumlah indikator adalah sebanyak 13 indikator, sehingga sampel yang digunakan adalah sebanyak 130 responden. Skala pengukuran yang digunakan dalam penelitian ini diukur dengan menggunakan skala Likert dengan lima tingkatan. Teknik analisis

Tabel 1. Klasifikasi Variabel dan Indikator Variabel

\begin{tabular}{|c|c|c|c|}
\hline $\begin{array}{c}\text { Klasifikasi } \\
\text { Variabel }\end{array}$ & Variabel & Indikator & Sumber \\
\hline \multirow[t]{6}{*}{ Eksogen } & \multirow{3}{*}{$\begin{array}{l}\text { Store Environ- } \\
\text { ment (X1) }\end{array}$} & Social Factor (X1.1) & \multirow{3}{*}{ Kumar (2010) } \\
\hline & & Design Factor (X1.2) & \\
\hline & & Ambient Factor (X1.3) & \\
\hline & \multirow{3}{*}{$\begin{array}{l}\text { Time Pressure } \\
\quad(\mathrm{X} 2)\end{array}$} & Keterbatasan waktu (X2.1) & \multirow{3}{*}{$\begin{array}{c}\text { Tafesse dan } \\
\text { Korneliussen } \\
\quad(2012)\end{array}$} \\
\hline & & Terburu - buru (X2.2) & \\
\hline & & Merasa lebih cepat (X2.3) & \\
\hline \multirow[t]{7}{*}{ Endogen } & \multirow{3}{*}{$\begin{array}{c}\text { Emotional State } \\
\text { (Y1) }\end{array}$} & Senang (Y1.1) & \multirow{3}{*}{$\begin{array}{l}\text { Rachmawati } \\
\text { (2009) }\end{array}$} \\
\hline & & Puas (Y1.2) & \\
\hline & & Bangga (Y1.3) & \\
\hline & \multirow{4}{*}{$\begin{array}{l}\text { Pembelian Im- } \\
\text { pulsif (Y2) }\end{array}$} & Membeli spontan (Y2.1) & \multirow{4}{*}{$\begin{array}{l}\text { Yistiani et al. } \\
\quad(2012)\end{array}$} \\
\hline & & Membeli tanpa berkpikir akibat (Y2.2) & \\
\hline & & Membeli terburu - buru (Y2.3) & \\
\hline & & $\begin{array}{l}\text { Membeli dengan dipengaruhi keadaan emosional } \\
\text { (Y2.4) }\end{array}$ & \\
\hline
\end{tabular}

Sumber: data yang diolah (2014) 
Enrique Made Reidia Gana Purwa \& Ni Nyoman Kerti Yasa / Strategi Store Environment dan Time Pressure ...

data yang digunakan adalah Structural Equation Modelling (SEM). Selain itu, dilengkapi dengan Uji Sobel untuk mengetahui peran emotional state sebagai variabel mediasi.

\section{HASIL DAN PEMBAHASAN}

Karakteristik responden yang dibahas pada penelitian ini meliputi jenis kelamin, umur, tingkat pendidikan, pekerjaan, dan tingkat pendapatan. Berdasarkan kroteria responden tersebut, menunjukkan bahwa jumlah responden berdasarkan jenis kelamin didominasi oleh responden perempuan sebanyak 96 orang $(73,85 \%)$, sedangkan respondenlaki-lakisebanyak34 orang $(26,15 \%)$. Berdasarkan kriteria kedua, diketahui bahwa responden memiliki umur berkisar antara 17-24 tahun sebanyak 11 orang $(8,46 \%)$, diikuti usia 25-34 tahun sebanyak 34 orang $(26,15 \%)$, usia 35-44 tahun sebanyak 37 orang $(28,46 \%)$, usia 45-54 tahun sebanyak 29 orang (22,31\%), dan usia $\geq 55$ sebanyak 19 orang $(14,62 \%)$.

Penelitian ini menunjukkan bahwa dari 130 orang responden dalam kriteria pendidikan, didominasi oleh perguruan tinggi atau akademi dengan persentase $58,46 \%$, kemudian diikuti dengan SMA atau sederajat dengan persentase $22,31 \%$, dan terakhir diploma dengan persentase sebesar 19,23\%. Pada kriteria pekerjaan, responden yang tergolong siswa memiliki persentase sebesar $8,46 \%$, lalu PNS sebesar $33,08 \%$, pegawai swasta sebesar $36,92 \%$, dan kemudian wiraswasta sebesar $21,54 \%$.

Dari data di atas juga dapat diketahui, bahwa responden yang memiliki pendapatan kisaran Rp 2.000.000,00 ke bawah berjumlah 14 orang $(10,77 \%)$, kemudian untuk pendapatan Rp 2.500.000,00-Rp 3.500.000,00 berjumlah 26 orang $(20,00 \%)$, pendapatan Rp 4.000.000,00Rp 5.000.000,00 berjumlah 57 orang (43,85\%), dan pendapatan di atas $\mathrm{Rp} 5.000 .000$,berjumlah 33 orang $(25,38 \%)$. Adapun hasil uji validitas instrumen dapat dilihat pada Tabel 3.

Sugiyono (2010) menyatakan bahwa validitas dapat dilakukan dengan mengkorelasikan antara skor faktor dengan skor total dan bila korelasi tiap faktor tersebut bernilai positif $(r>0,3)$. Tabel 2 menunjukkan bahwa, hasil uji validitas dari 13 variabel yang diteliti menghasilkan korelasi yang terkecil adalah 0,793 dan korelasi terbesar adalah

Tabel 2. Hasil Uji Validitas

\begin{tabular}{cccc}
\hline Faktor & Variabel & Koefisien Korelasi & Keterangan \\
\hline Store Environment & X1.1 & 0,900 & Valid \\
& X1.2 & 0,870 & Valid \\
& X1.3 & 0,871 & Valid \\
Time Pressure & X2.1 & 0,943 & Valid \\
& X2.2 & 0,937 & Valid \\
Emotional State & X2.3 & 0,966 & Valid \\
& Y1.1 & 0,793 & Valid \\
Pembelian Impulsif & Y1.2 & 0,895 & Valid \\
& Y1.3 & 0,917 & Valid \\
& Y2.1 & 0,901 & Valid \\
& Y2.3 & 0,823 & Valid \\
& Y2.4 & 0,911 & Valid \\
& & 0,925 & Valid \\
\hline
\end{tabular}

Sumber: data yang diolah (2014) 
Tabel 3. Hasil Uji Reliabilitas

\begin{tabular}{cccc}
\hline Faktor & Jumlah Variabel & Alpha Cronbach & Keterangan \\
\hline Store Environment & 3 & 0,855 & Reliabel \\
Time Pressure & 3 & 0,944 & Reliabel \\
Emotional State & 3 & 0,836 & Reliabel \\
Pembelian Impulsif & 4 & 0,913 & Reliabel \\
\hline
\end{tabular}

Sumber: data yang diolah (2014)

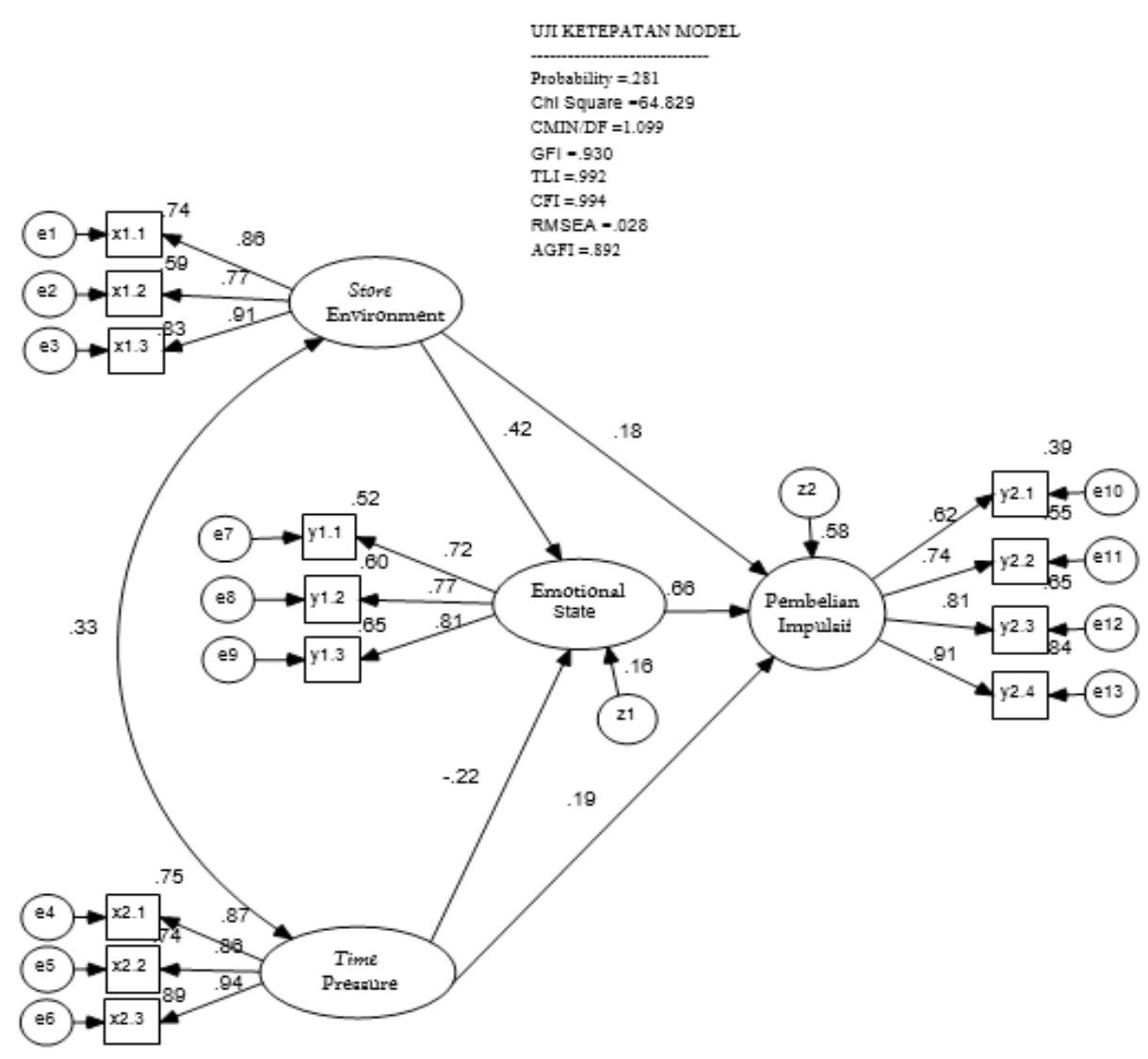

\section{Gambar 2. Structural Model}

0,966 yang berarti memiliki validitas sangat tinggi. Dengan demikian, hasil uji validitas yang dilakukan dengan kuisioner dalam penelitian ini adalah valid karena nilai koefisiennya diatas 0,3 .

Teknik yang digunakan untuk menguji reliabilitas butir pernyataan dalam studi ini adalah metode uji reliabilitas koefisien variant alpha (Sugiyono, 2010) dengan program SPSS. Standar nilai reliabilitas instrumen memiliki nilai $\mathrm{r}>0,6$. Adapun hasil uji reliabilitas instrument dapat dilihat pada Tabel 4. Hasil olah data ditunjukkan dalam struktural model pada Gambar 2.
Tabel 3 menunjukkan bahwa, hasil perhitungan reliabilitas seluruh instrumen adalah reliabel karena memperoleh koefesien Alpha Cronbach lebih besar dari 0,6. Hal ini menunjukkan bahwa pengukuran tersebut dapat memberikan hasil yang konsisten apabila dilakukan pengukuran kembali terhadap subyek yang sama.

Evaluasi model secara keseluruhan dilakukan melalui kriteria Goodness of Fit. Hasil analisis struktural dapat dilihat pada Gambar 2. Selanjutnya pada Tabel 4 menunjukkan bahwa, keseluruhan pengukuran goodness-of- 
Enrique Made Reidia Gana Purwa \& Ni Nyoman Kerti Yasa / Strategi Store Environment dan Time Pressure ...

Tabel 4. Kriteria Goodness of Fit

\begin{tabular}{ccccc}
\hline No & Goodness of Fit Index & Nilai Kritis & Nilai Model & Kesimpulan \\
\hline 1 & Chi Square & Diharapkan nilai lebih & 64,829 & Fit \\
2 & kecil & $>0,05$ & 0,281 & Fit \\
3 & $\geq 0,90$ & 0,930 & Fit \\
4 & GMIN/DF & $\leq 2,00$ & 1,009 & Fit \\
5 & TLI & $\geq 0,95$ & 0,992 & Fit \\
6 & CFI & $\geq 0,95$ & 0,994 & Fit \\
7 & RMSEA & $<0,08$ & 0,028 & Fit \\
8 & AGFI & $\geq 0,90$ & 0,892 & Marginal \\
\hline
\end{tabular}

Sumber: daya yang diolah (2014)

Tabel 5. Regression Weights

\begin{tabular}{|c|c|c|c|c|c|c|}
\hline \multicolumn{3}{|c|}{ Pengaruh Langsung } & \multirow{2}{*}{$\begin{array}{c}\text { Estimate } \\
.336\end{array}$} & \multirow{2}{*}{$\begin{array}{l}\text { S.E. } \\
.088\end{array}$} & \multirow{2}{*}{$\frac{\text { C.R. }}{3.813}$} & \multirow{2}{*}{$\frac{\mathrm{P}}{* * *}$} \\
\hline Emotional_State & $<---$ & Store_Environment & & & & \\
\hline Pembelian_Impulsif & $<---$ & Store_Environment & .146 & .073 & 1.991 & .046 \\
\hline Emotional_State & $<---$ & Time_Pressure & -.131 & .062 & -2.102 & .036 \\
\hline Pembelian_Impulsif & $<---$ & Time_Pressure & .113 & .050 & 2.238 & .024 \\
\hline Pembelian_Impulsif & $<---$ & Emotional_State & .666 & .106 & 6.261 & $* * *$ \\
\hline
\end{tabular}

Sumber: data yang diolah (2014)

fit model penelitian sesuai dengan kriteria nilai kritis, kecuali untuk nilai Adjusted Goodness of Fit Index (AGFI) dalam model ini adalah 0,882 menunjukkan indikasi marginal. Namun menurut Salisbury et al. (2001) dan Cheng (2001) merekomendasikan AGFI minimum 0,80 . Dengan demikian, model secara keseluruhan adalah fit dengan data.

\section{Pengujian Hipotesis}

Tahap selanjutnya adalah analisis terhadap hubungan-hubungan struktural model (pengujian hipotesis). Tabel 5 menunjukkan tidak ada nilai critical ratio (CR) yang sama dengan nol, sehingga hipotesis nol ditolak dan menunjukkan bahwa:

1) Hipotesis 1 diterima dengan nilai estimasi sebesar 0,336 pada $\mathrm{p}$ value sebesar 0,000 .

2) Hipotesis 2 diterima dengan nilai estimasi sebesar 0,146 pada $\mathrm{p}$ value sebesar 0,046 .

3) Hipotesis 3 diterima dengan nilai estimasi sebesar -0,131 pada $\mathrm{p}$ value sebesar 0,036.

4) Hipotesis 4 diterima dengan nilai estimasi sebesar 0,113 pada $\mathrm{p}$ value sebesar 0,024 .

5) Hipotesis 5 diterima dengan nilai estimasi sebesar 0,666 pada $\mathrm{p}$ value sebesar 0,000 .

Pada Tabel 6, menunjukkan estimate dan standard error sebagai syarat untuk menghitung peran mediasi menggunakan uji Sobel. Dari hasil tersebut, selanjutnya dilakukan perhitungan dengan menggunakan rumus Sobel sebagai berikut:

$$
\begin{aligned}
\mathrm{S}_{\mathrm{ab}} & =\sqrt{\mathrm{b}^{2} \mathrm{Sa}^{2}+\mathrm{a}^{2} \mathrm{Sb}^{2}+\mathrm{Sa}^{2} \mathrm{Sb}^{2}} \\
& =\sqrt{0,666^{2} * 0,088^{2}+0,336^{2} * 0,106^{2}+0,088^{2} * 0,106^{2}} \\
& =0,0692
\end{aligned}
$$


Tabel 6. Hasil Koefisien Jalur dan Standard Error

\begin{tabular}{|c|c|c|c|c|}
\hline & & & Estimate & S.E. \\
\hline Emotional State & $<---$ & Store Environment & .336 & .088 \\
\hline Pembelian_Impulsif & $<---$ & Emotional_State & .666 & .106 \\
\hline
\end{tabular}

Tabel 7. Hasil Koefisien Jalur dan Standard Error

\begin{tabular}{lllcc}
\hline & & & Estimate & S.E. \\
\hline Emotional_State & $<---$ & Time Pressure & -.131 & .062 \\
Pembelian_Impulsif & $<---$ & Emotional_State & .666 & .106 \\
\hline
\end{tabular}

Sumber: data yang diolah (2014)

Sehingga Nilai $Z_{a b}$ dapat dihitung sebagai berikut:

$$
\begin{aligned}
Z_{a b} & =\frac{e_{a b}}{s_{a b}} \\
& =\frac{0,336^{*} 0,666}{0,0692} \\
& =3,2337
\end{aligned}
$$

Sedangkan, nilai signifikansi dapat dihitung sebagai berikut:

$$
\begin{aligned}
\operatorname{Sig} & =(1-\text { NORMDIST }(3,2337))^{*} 2 \\
& =0,001
\end{aligned}
$$

Hasil pengujian menunjukkan bahwa emotional state dapat memediasi pengaruh store environment terhadap pembelian impulsif secara signifikan. Hal ini ditunjukkan dengan nilai $\mathrm{Z}_{\mathrm{ab}}=$ 3,2337> 1,96 dengan tingkat signifikan 0,001 < 0,05. Dengan demikian, H6 didukung.

Pada Tabel 7, menunjukkan estimate dan standard error sebagai syarat untuk menghitung peran mediasi menggunakan uji Sobel. Dari hasil tersebut, selanjutnya dilakukan perhitungan dengan menggunakan rumus Sobel sebagai berikut:

$$
\begin{aligned}
\mathrm{S}_{\mathrm{ab}} & =\sqrt{\mathrm{b}^{2} \mathrm{Sa}^{2}+\mathrm{a}^{2} \mathrm{Sb}^{2}+\mathrm{Sa}^{2} \mathrm{Sb}^{2}} \\
& =\sqrt{0,666^{2} * 0,062^{2}+(-0,131)^{2} * 0,106^{2}+0,062^{2} * 0,106^{2}} \\
& =0,0441
\end{aligned}
$$

Sehingga Nilai $\mathrm{Z}_{\mathrm{ab}}$ dapat dihitung sebagai berikut:

$$
\begin{aligned}
Z_{a b} & =\frac{e_{a b}}{s_{a b}} \\
& =\frac{0,336^{*} 0,666}{0,0692} \\
& =-1,9784
\end{aligned}
$$

Sedangkan, nilai signifikansi dapat dihitung sebagai berikut:

$$
\begin{aligned}
\text { Sig } & =(1-\operatorname{NORMDIST}(-1,9784))^{* 2} \\
& =0,048
\end{aligned}
$$

Hasil pengujian menunjukkan bahwa emotional state dapat memediasi pengaruh time pressure terhadap pembelian impulsif secara signifikan. Hal ini ditunjukkan dengan nilai $\mathrm{Z}_{\mathrm{ab}}=-1,9784>1,96$ dengan tingkat signifikan $0,048<0,05$. Dengan demikian, H7 didukung.

Hasil penelitian ini sejalan dengan penelitian yang dilakukan oleh Chang et al. (2009) dan Octaprinanta et al. (2013) yang mengimplikasikan semakin tinggi store environment atau komponen lingkungan toko yang dirasakan oleh konsumen Tiara Dewata Super Market, maka semakin tinggi Emotional State atau suasana hati yang dirasakan saat melakukan pembelanjaan di Tiara Dewata Super Market. Dengan ini, lingkungan toko mampu 
Enrique Made Reidia Gana Purwa \& Ni Nyoman Kerti Yasa / Strategi Store Environment dan Time Pressure ...

memberikan kesenangan dan merangsang suasana hati konsumen di Tiara Dewata Super Market.

Pengaruh Store Environment terhadap Pembelian Impulsif

Hasil penelitian ini sejalan dengan penelitian yang dilakukan oleh dan Tendai dan Crispen (2009); Chen dan Hseih (2011); Myriam dan Oesman (2013), yang juga mengimplikasikan semakin tinggi store environment atau komponen lingkungan toko yang dirasakan oleh konsumen Tiara Dewata Super Market, maka semakin tinggi pembelian impulsif yang dilakukan saat melakukan pembelanjaan di Tiara Dewata Super Market. Penjelasan tersebut juga menunjukkan bahwa pembelian impulsif tampaknya dimotivasi oleh visual konfrontasi dengan produk atau rangsangan lingkungan toko di Tiara Dewata Super Market.

\section{Pengaruh Time Pressure terhadap Emotional State}

Hasil penelitian ini sejalan dengan penelitian yang dilakukan oleh Graa dan DanielKebir (2012) dan Octaprinanta et al. (2013) serupa mengimplikasikan semakin tinggi time pressure yang dirasakan, maka semakin menurun emotional state yang dirasakan konsumen saat berbelanja atau semakin rendah time pressure yang dirasakan, maka semakin meningkat emotional state yang dirasakan. Artinya saat berbelanja di Tiara Dewata Super Market, time pressure yang rendah dapat memanipulasi emosi konsumen sehingga menjadi positif.

\section{Pengaruh Time Pressure terhadap Pembelian Impulsif}

Hasil penelitian ini sejalan dengan penelitian yang dilakukan oleh $\mathrm{Hu}$ dan Qin (2014) dan Wu dan Huan (2010) yang mengimplikasikan semakin tinggi time pressure atau tekanan waktu yang dirasakan oleh konsumen Tiara Dewata Super Market, maka semakin tinggi pembelian impulsif yang dilakukan saat melakukan pembelanjaan di Tiara Dewata Super Market. Hal ini mungkin disebabkan oleh fakta bahwa tidak ada waktu yang cukup bagi konsumen untuk mengambil banyak hal yang menjadi pertimbangan, sehingga dapat meningkatkan kemungkinan konsumen untuk melakukan pembelian yang tak terencana sebelumnya di Tiara Dewata Super Market.

\section{Pengaruh Emotional State sebagai Mediasi ter- hadap Pembelian Impulsif}

Hasil penelitian ini sejalan dengan penelitian yang dilakukan oleh Lee dan Yi (2008) dan Tendai dan Crispen (2009), yang mengimplikasikan semakin tinggi emotional state atau suasana hati yang dirasakan oleh konsumen Tiara Dewata Super Market, maka semakin tinggi pembelian impulsif yang dilakukan saat melakukan pembelanjaan di Tiara Dewata Super Market. Semua ini menunjukkan bahwa pembelian impulsif, mungkin sebagian besar menjadi perilaku pembelian sadar yang didorong oleh kekuatan afektif di luar kendali individu seperti emosi.

Peran Emotional State dalam Memediasi Pengaruh Store Environment Terhadap Pembelian Impulsif

Hasil penelitian ini sejalan dengan penelitian yang dilakukan oleh Jondry (2012) dan Sinaga et al. (2012) yang mengimplikasikan peningkatan stimulus lingkungan toko yang teraktualisasi dalam hal penataan lingkungan toko dan stimulus yang diberikan dapat merangsang emosi positif konsumen sehingga dapat memicu terjadinya pembelian impulsif.

Peran Emotional State dalam Memediasi Pengaruh Time Pressure dengan Pembelian Impulsif

Hasil penelitian ini mendukung hasil penelitian Octaprinanta et al. (2013) 
dan Graa dan Dani-elKebir (2012) yang mengemukakan bahwa ada pengaruh emotional state sebagai mediasi antara time pressure dan pembelian impulsif. Hal ini terjadi karena dalam pengaruh tidak langsung antara time pressure dan pembelian impulsif, emotional state menunjukkan pengaruh dari time pressure terhadap pembelian impulsif. Dengan kata lain, emosi yang dirasakan akibat dari rendahnya tekanan waktu saat berbelanja menjadi positif dan berpengaruh terhadap pembelian impulsif.

Beberapa keterbatasan penelitian yang dapat ditarik dari penelitian ini sebagai berikut: 1) penelitian ini terbatas atau terfokus pada satu perusahaan retail yaitu Tiara Dewata Super Market, sehingga hasil penelitian mungkin tidak dapat digeneralisasikan pada perusahaanperusahaan lain yang sejenis dan 2) pada saat pengisian kuesioner, beberapa responden tidak dapat membaca kuesioner dengan jelas, sehingga peneliti harus membantu responden, kemungkinan pengarahan pikiran dapat saja terjadi serta kemungkinan terjadi kesalahan dalam menginterpretasi pertanyaan yang disediakan.

Hasil penelitian ini diharapkan berguna bagi pihak manajemen Tiara Dewata Super Market untuk membantu dalam meningkatkan jumlah kunjungan, dan peningkatan pembelian dengan pengoptimalan dari store environment yang terdiri dari design factor, ambient factor, dan social factor. Hasil penelitian juga diharapkan agar menjadi masukan untuk perbaikan dan menata hal-hal yang kurang menarik seperti dekorasi, warna interior dan penambahan papan-papan petunjuk yang jelas, sehingga memberi kemudahan dan kenyamanan kepada konsumen dalam berbelanja.

\section{SIMPULAN DAN SARAN}

Berdasarkan analisis dan pembahasan pada bagian sebelumnya, maka dapat ditarik kesimpulan sebagaiberikut:(1) storeenvironment berpengaruh positif dan signifikan terhadap emotional state. Dengan kata lain, semakin tinggi store environment yang dirasakan oleh konsumen maka semakin positif emotional state yang dirasakan konsumen. Artinya kehadiran store environment atau lingkungan toko yang memadai dapat meningkatkan emotional state atau emosi yang positif pada konsumen saat berbelanja di Tiara Dewata Super Market; (2) store environment berpengaruh positif dan signifikan terhadap pembelian impulsif. Dengan kata lain, semakin tinggi store environment yang dirasakan oleh konsumen maka semakin positif emotional state yang dirasakan konsumen.

Artinya kehadiran store environment atau lingkungan toko yang memadai dapat meningkatkan emotional state atau emosi yang positif pada konsumen saat berbelanja di Tiara Dewata Super Market; (3) time pressure berpengaruh negatif dan signifikan terhadap emotional state. Artinya tekanan waktu rendah yang dirasakan oleh konsumen saat berbelanja di Tiara Dewata Super Market, dapat meningkatkan dimensi emosi konsumen, sehingga semakin rendah time pressure, maka semakin meningkat emosi atau emotional state dalam melakukan perbelanjaan di Tiara Dewata Super Market; (4) time Pressure berpengaruh positif dan signifikan terhadap emotional state. Semakin tinggi time pressure yang dirasakan oleh konsumen, maka semakin tinggi pembelian impulsif yang dilakukan konsumen. Artinya dengan kehadiran tekanan waktu yang dirasakan oleh konsumen saat berbelanja, dapat mendorong seorang konsumen untuk melakukan pembelian yang tidak terencanakan sebelumnya di Tiara Dewata Super Market; (5) emotional state berpengaruh positif dan signifikan terhadap pembelian impulsif.

Semakin tinggi time pressure yang dirasakan oleh konsumen, maka semakin tinggi pembelian impulsif yang dilakukan konsumen. Artinya dengan kehadiran tekanan waktu yang dirasakan oleh konsumen saat berbelanja, dapat mendorong seorang konsumen untuk melakukan pembelian yang tidak terencanakan sebelumnya di Tiara Dewata Super Market; (6) emotional state secara signifikan memediasi hubungan antara store environment dengan pembelian impulsif konsumen di Tiara Dewata 
Super Market. Dengan kata lain, bahwa store environment berpengaruh pada pembelian impulsif melalui emotional state. Semakin tinggi store environment yang dirasakan oleh konsumen, maka semakin tinggi emotional state yang mana hal ini akan meningkatkan pembelian impulsif saat berbelanja di Tiara Dewata Super Market serta (7) emotional state secara signifikan memediasi hubungan antara time pressure dengan pembelian impulsif. Dengan kata lain, bahwa time pressure berpengaruh pada pembelian impulsif melalui emotional state. Hal ini menunjukkan bahwa konsumen yang merasakan tekanan waktu rendah, tentu merasakan emosi yang positif saat berbelanja serta menunjukkan perilaku pembelian impulsif di Tiara Dewata Super Market.

Berdasarkan hasil penelitian yang diperoleh,makasaran-saranyangdapatdiberikan adalah: (1) untuk pihak Tiara Dewata Super Market, diharapkan dapat menata lingkungan toko yang teratur dengan interior yang lebih nyaman dan menarik guna membentuk emosi positif dan meningkatkan pembelian impulsif konsumen saat berbelanja; (2) untuk pihak Tiara Dewata Super Market, perlu untuk lebih intens dalam menginformasikan produkproduk yang dijual khususnya barang baru, guna membentuk pemahaman konsumen tentang persediaan barang di Tiara Dewata Super Market, sehingga mudah mengakses produk khususnya konsumen yang memiliki tekanan waktu; (3) untuk pihak Tiara Dewata Super Market, perlu meningkatkan kemampuan karyawan dalam hal melayani konsumen, hal ini disebabkan berdasarkan hasil studi menunjukkan bahwa konsumen cenderung melakukan pembelian impulsif dikarenakan respons yang cepat dari karyawan dalam hal menerangkan spesifikasi produk dan membantu mereka dalam mencari produk yang diinginkan.

Untuk penelitian selanjutnya, diharapkan mengembangkan model penelitian dengan menambah variabel baru, seperti kepadatan (dentisity), keadaan berdesakan (crowding) pada social factor, cara pembayaran dan atau faktor-faktor situasional lainnya serta (5) untuk penelitian selanjutnya, juga dapat memperluas cakupan penelitian dengan membandingkan perilaku berbelanja khususnya impulse buying antara pria dan wanita.

\section{DAFTAR PUSTAKA}

Belk, W. R. 1975. Situational Variables and Consumer Behavior. Journal of Consumer Research. 2 (3): 157-164.

Chang, H., Eckman, M \& Yan, R. 2009. Impulse Buying Behavior of Apparel: Application of the S-O-R Model and the Moderating Effect of Hedonic Motivation. ITAA Proceedings. 306-320.

Chen, H \& Hsieh, T. 2011. The Effect of Atmosphere on Customer Perceptions and Customer Behavior Responses in Chain Store Supermarkets. African Journal of Business Management. 5 (24): 10054-10066.

Cheng, C. 2001. Assessing Coping Flexibility in RealLife and Laboratory Settings: A MultiMethod Approach. Journal of Personality and Social Psychology. 80: 814-833.

Engel, J., Blackwell, R. D \& Miniard, P. W. 2008. Perilaku Konsumen. Alih bahasa: Budyanto. Jilid I. Jakarta: Binarupa Aksara Publisher.

Ferdinand, A. 2002. Structural Equation Modeling dalam Penelitian Manajemen: Aplikasi Model-Model Rumit Untuk Tesis Magister dan Disertasi Doktor. Semarang: Fakultas Ekonomi Undip.

Foroughi, A., Buang, N. A., Senik, Z. C \& Hajmisadeghi, R. 2013. Impulse Buying Behavior and Moderating Role of Gender among Iranian Shoppers. Journal of Basic and Applied Scientific Research. 3 (4): 760-769.

Graa, A \& Dani-elKebir, M. 2012. Application of Stimulus \& Response Model to Impulse Buying Behavior of Algerian Consumers. Serbian Journal of Management. 7 (1): 53-64.

$\mathrm{Hu}, \mathrm{M} \&$ Qin, X. 2014. Time Pressure Effects on Impulse Buying In Sales Situation: Need Cognitive Closure of Intermediary Role. Advanced Materials Research, 926-930. 40654068.

Jondry, A. H. 2012. Model Kecenderungan Pembelian Impulsif (Studi pada Konsumen Matahari Departement Store Kota Ambon). Jurnal Manajemen Teknologi. 11 (3): 34-45. 
Kumar, A. 2010. The Effect of Store Environment on Consumer Evaluations and Behavior Toward Single-Brand Apparel Retailers. Journal of Trace: Tennessee Research and Creative Exchange. 1 (4): 28-56.

Lee, G. Y \& Yi, Y. 2008. The Effect of Shopping Emotions and Perceived Risk on Impulsive Buying: The Moderating Role of Buying Impulsiveness Trait. Seoul Journal of Business. 14 (2): 78-86.

Lee, J. A \& Kacen, J. J. 2008. The Influence of Culture on Consumer Impulsive Buying Behavior. Journal Of Consumer Pshycology. 12 (2): 163-176.

Mehrabian, A \& Russell, A. 1974. An approach to environmental psychology. Cambridge, Mass: MIT Press.

Mihic, M \& Kursan, I. 2010. Assessing The Sitauational Factors and Impulsive Buying Behavior: Market Segmentation Approach. Journal of Management. 15 (2): 47-66.

Mowen, J. C \& Minor, M. 2002. Perilaku Konsumen. Alih Bahasa: Dwi Kartini Yahya. Jilid 2. Jakarta: Erlangga.

Muruganantham, G \& Bhakat, R. S. 2013. A Review of Impulse Buying Behavior. International Journal of Marketing Studies. 5 (3): 148-160.

Myriam, K \& Osman, B. H. 2013. The Negative Aspects of A Store Environment: Definition and Relevance of Retailers. Journal of Global Management Research. 18 (7): 6-28.

Nistorescu, T \& Barbu, C. M. 2008. Retail Store Design and Environmentas Branding Support in The Services Marketing. Management of Marketing Craiova (Management \& Marketing Craiova. 1 (08): 118-138.

Octaprinanta, N., Kumadji, S \& Hidayat, K. 2013. Pengaruh Faktor Situasional Terhadap Emotional States dan Impulse Buying (Survei pada Pengunjung Giant Hypermarket Mall Olympic Garden Malang). Jurnal Aplikasi Manajemen. 9 (4): 88-96.

Rachmawati, V. 2009. Hubungan antara Hedonic Shopping Value, Positive Emotion, dan Perilaku Impulse Buying pada Konsumen Ritel. Majalah Ekonomi. 19 (2): 192-209.

Rohman, F. 2009. Peran Nilai Hedonik Konsumsi dan Reaksi Impulsif sebagai Mediasi Pengaruh Faktor Situasional terhadap Keputusan Pembelian Impulsif di Butik Kota
Malang. Jurnal Aplikasi Manajemen. 7 (2): 251-261.

Salisbury, W. D., Pearson, R. A., Pearson, A. W \& Miller, D. W. 2001. Perceived Security and Worldwide Web Purchase Intention. Industrial Management \& Data Systems. 101 (4): 165-177.

Santoso,S. 2007. Structural Equation Modeling Konsep dan Aplikasi dengan AMOS. Jakarta : PT. Elex Media Komputindo.

Sinaga, I., Suharyono \& Kumadji, S. 2012. Stimulus Store Environment dalam Menciptakan Emotional Response Dan Pengaruhnya terhadap Impulse Buying (Survei pada Pembeli di Carrefour Mitra I Malang). Jurnal Profit. 6 (2): 1-14.

Solomon, R. M. 2009. Customer Behaviour: A European Perspective. Financial Times. New Jersey: Prentice Hall.

Sugiyono. 2010. Metode Penelitian Bisnis. Bandung: Alfabeta.

Suprapti, N. W. S. 2010. Perilaku Konsumen : Pemahaman Dasar dan Aplikasinya dalam Strategi Pemasaran. Bali: Udayana University Press.

Sutisna. 2001. Perilaku Konsumen dan Komunikasi Pemasaran. Bandung: Cetakan I.

Tafesse, W \& Korneliussen, T. 2012. Factor Affecting Consumer Visitor Buying Behavior at Retail Trade Show. Journal of Retailing and Consumer Services. 19 (4): 438-444.

Tendai, M \& Crispen, C. 2009. In-Store Shopping Environment and Impulsive Buying. African Journal of Marketing Management. 1 (4): 102-108.

Utami, C. W. 2010. Manajemen Ritel (Strategi dan Implementasi Operasional Bisnis Ritel Modern di Indonesia). Jakarta : Salemba Empat.

Wu, C \& Huan, T. 2010. The effect of purchasing situation and conformity behavior on young students' impulse buying. African Journal of Business Management. 4 (16): 3530-3540.

Yistiani, Manik, N. N., Yasa, N. N. K \& Suasana, I. G. A. K. G. 2012. Pengaruh Atmosfer Gerai dan Pelayanan Ritel Terhadap Nilai Hedonik dan Pembelian Impulsif Pelanggan Matahari Departement Store Duta Plaza Di Denpasar. Jurnal Manajemen, Strategi Bisnis, dan Kewirausahaan. 6 (2): 139-149. 